\title{
Pengembangan Model Bimbingan Kelompok Berbasis Nilai-Nilai Budaya Huma Betang Untuk Mengurangi Prasangka Sosial Siswa
}

\author{
Dony Apriatama \\ Program Studi Bimbingan Konseling Islami, Fakultas Ushuluddin Adab dan \\ Dakwah, Institut Agama Islam Negeri Palangka Raya \\ Apriatamadony@gmail.com
}

\begin{abstract}
Abstrak
Sikap prasangka sosial yang ditunjukkan oleh siswa SMA Negeri Palangka Raya seperti sikap memilih-milih teman, terisolir dalam kelompok tertentu, mengedepankan kepentingan kelompok sendiri di atas kepentingan kelompok lain, menunjukkan sikap perlawanan terhadap kelompok lain, menunjukkan otorisasi kelompok sendiri, timbul rasa dendam dan acuh tak acuh terhadap kelompok lain. Upaya untuk mengurangi sikap prasangka sosial tersebut dengan menginternalisasikan nilai-nilai budaya huma betang ke dalam layanan bimbingan kelompok. Hasil penelitian menunjukkan bahwa model bimbingan kelompok berbasis nilai-nilai budaya huma betang efektif mengurangi prasangka sosial siswa. Hal ini ditunjukkan dengan perubahan tingkat perilaku prasangka soial sebelum diberikan perlakuan (pre-test) dan setelah diberikan perlakuan (post-test) sebesar 30,12\%.
\end{abstract}

Kata kunci : pengembangan model bimbingan kelompok., nilai-nilai budaya huma betang., prasangka sosial.

\section{Pendahuluan}

Indonesia merupakan negara yang terdiri dari beragam suku, budaya, adatistiadat, agama dan bahasa. Keseluruhan aspek tersebut melatarbelakangi perbedaan karakteristik individu. Untuk memperkuat karakteristik itu, individu mencari kesamaan-kesamaan dengan individu lainnya dengan membentuk suatu komunitas sebagai identitas sosial. Jika potensi ini mendapat perhatian yang baik maka keragaman tersebut merupakan kekayaan bagi bangsa. Namun sebaliknya jika tidak dikelola dengan baik akan menjadi potensi sebagai pemecah kesatuan dan persatuan bangsa.

Salah satu pemicu konflik yang terjadi karena keanekaragaman budaya adalah prasangka sosial. Prasangka sosial menurut Manstead dan Hewstone Jurnal Insight Fakultas Psikologi Universitas Muhammadiyah Jember | 236 
(dalam Rahman, 2002: 3) di definisikan sebagai "suatu keadaan yang berkaitan dengan sikap-sikap dan keyakinan-keyakinan yaitu ekspresi perasaan negatif, penunjukkan sikap bermusuhan atau perilaku diskriminatif terhadap anggota kelompok lain'. Lebih lanjut Manstead dan Hewtone menjelaskan prasangka sosial pada mulanya hanya merupakan sikap-sikap perasaan negatif, lambat laun menyatakan dirinya dalam tindakan-tindakan yang diskriminatif terhadap orangorang yang termasuk golongan yang diprasangkai tanpa terdapat alasan-alasan yang objektif pada pribadi orang yang dikenakan tindakan-tindakan diskriminatif.

Ketidaksukaan terhadap suatu kelompok yang berlangsung terus-menerus akibatnya dapat mengakibatkan penurunan harga diri seseorang yang menjadi target prasangka, meningkatkan kebencian ekstrim, bahkan dapat diikuti dengan tindakan menyiksa dan membunuh. Beberapa konflik yang terjadi di Indonesia lebih cenderung berbau SARA (suku, ras, dan agama). Konflik skala besar terjadi di beberapa daerah di Indonesia seperti di Sambas, Ambon, Poso, Lampung, Sampit, dan Tarakan yang pangkalnya karena stereotipe yang mengarah pada prasangka. Khususnya kerusuhan etnis di sampit pada tahun 2001 yang meluas sampai ke Palangka Raya dan akhirnya keseluruh penjuru di Kalimantan Tengah (dalam http://mediapublikonline: 2002).

Konflik antar kelompok juga terjadi di lingkungan pendidikan. Kasus tawuran antar pelajar di indonesia pada tahun 2010, setidaknya terjadi 128 kasus tawuran antar pelajar. Angka itu melonjak tajam lebih dari 100\% pada 2011, yakni 330 kasus tawuran yang menewaskan 82 pelajar. Pada Januari-Juni 2012, telah terjadi 139 tawuran yang menewaskan 12 pelajar. (dalam http://video.tvonenews.tv : 2013). Di kota Palangkaraya juga nyaris terjadi konflik antar pelajar yang hanya disebabkan persoalan yang sepele (dalam Tabengan, 16 Agustus 2014).

Bimbingan dan konseling yang merupakan bagian integral dari sistem pendidikan juga memiliki peran sentral untuk mengurangi masalah-masalah sosial pada diri siswa. Layanan bimbingan kelompok secara konseptual dinilai efektif dalam memberikan intervensi-intervensi positif kepada peserta didik. Menurut Sukardi (2008: 64) menyatakan bahwa "layanan bimbingan kelompok memiliki 
tiga fungsi, yaitu 1) berfungsi informatif; 2) berfungsi pengembangan; dan 3) berfungsi preventif dan kreatif'. Berdasarkan pendapat Sukardi, ketika guru bimbingan dan konseling akan memberikan layanan yang sifatnya preventif dan pengembangan, layanan yang dianggap tepat adalah layanan bimbingan kelompok.

Meskipun layanan bimbingan kelompok memiliki keunggulan terutama dalam menangani masalah yang berkaitan dengan bidang sosial, upaya yang telah dilakukan oleh guru bimbingan dan konseling di SMA Negeri di Palangka Raya belum berhasil mengurangi prasangka sosial yang terjadi dikalangan siswa. Informasi yang peneliti peroleh dari wawancara, materi bimbingan kelompok di SMA Negeri di Palangka Raya yang diberikan hanya mengulang dari tahun-tahun sebelumnya yaitu materi tentang motivasi belajar dan materi belajar secara efektif, sehingga cenderung monoton dan kurang variatif. Bimbingan kelompok dilaksanakan dengan jumlah anggota lebih dari 12 orang yaitu 1 kelas identik dengan bimbingan klasikal dan pelaksanaanya pun tidak terjadwal secara khusus. Layanan yang bersifat kelompok cenderung dilaksanakan manakala ada siswa yang bermasalah, kondisi tersebut menunjukkan layanan bimbingan kelompok di SMA Negeri di Palangka Raya tidak diperuntuhkan untuk mengurangi prasangka sosial, karena layanan bimbingan kelompok yang dilaksanakan lebih bersifat kasuistik.

Hasil penyebaran skala prasangka sosial pada kelas $\mathrm{X}$ dari semua jurusan yang berjumlah 150 siswa di SMA N 2 Palangka Raya, menunjukkan bahwa prasangka sosial tinggi. Hal ditunjukkan dengan sikap siswa yang memilih-milih teman, terisolir dalam kelompok tertentu, mengedepankan kepentingan kelompok sendiri di atas kepentingan kelompok lain, menunjukkan sikap perlawanan terhadap kelompok lain, menunjukkan otorisasi kelompok sendiri, timbul rasa dendam dan acuh tak acuh terhadap kelompok lain.

Hurlock (2009: 257) menyatakan bahwa "perkembangan individu tidak terlepas atau dipengaruhi oleh budaya dimana individu itu berada". Peneliti berasumsi bahwa perkembangan prasangka sosial adalah masalah yang tidak terlepas dari etika dan budaya dalam berkelompok. Bimbingan kelompok yang 
dilaksanakan di SMA Negeri Palangka Raya belum menggunakan keragaman nilai-nilai budaya yang ada pada anggota kelompok sehingga solusinya adalah dengan mengangkat suatu tema yang kaya akan nilai-nilai sosial dan budaya. Untuk membantu para guru bimbingan dan konseling, peneliti akan melakukan penelitian guna menemukan suatu model yang dapat memberikan formula untuk mengurangi prasangka sosial.

Masyarakat di Palangka Raya memiliki suatu falsafah yang mengatur cara mereka bertingkah laku. Mengenai hal ini, Peraturan Daerah Provinsi Kalimantan Tengah Nomor 16 Tahun 2008 Tentang Kelembagaan Adat Dayak Di Kalimantan Tengah menggunakan istilah 'falsafah hidup "Budaya Huma Betang atau Belom Bahadat'.... yang diartikan sebagai perilaku hidup yang menjunjung tinggi kejujuran, kesetaraan, kebersamaan dan toleransi serta taat pada hukum (hukum negara, hukum adat dan hukum alam. Apabila telah mampu melaksanakan perilaku hidup "Belom Bahadat", maka akan teraktualisasi dalam wujud Belom Penyang Hinje Simpei" yaitu hidup berdampingan, rukun dan damai untuk kesejahteraan bersama".(Perda Kalteng No.16/2008: 11).

Dalam Musyawarah Rakyat Kabupaten/Kota diselenggarakan dalam bulan April-Mei 2001 dan Musyawarah Rakyat Kota Palangka Raya di laksanakan pada 24-27 April 2001. Kemudian Kongres Rakyat Kalimantan Tengah (KRKT) pada tanggal 4-7 Juni 2001 dengan lantang mengangkat kembali 2 motto lama antara lain: 1) "Dimana bumi dipijak disitu langit dijunjung" yang mempunyai makna setiap warga pendatang baru wajib menghormati budaya dan adat-istiadat masyarakat setempat dan 2) "Falsafah budaya hidup huma betang" dimaksudkan sebagai pedoman yang mengatur pergaulan hidup antar sesama warga masyarakat yang bersifat rukun dan damai, toleransi tinggi di antara sesama warga atau kelompok masyarakat yang berbeda. Kesimpulan umum yang diperoleh dari Musyawarah Rakyat Kabupaten/Kota maupun Musyawarah Rakyat Kota Palangka Raya (KRKT) bahwa konflik etnis yang terjadi pada 18 februari 2001 di Sampit akibat diabaikannya motto "Dimana bumi dipijak disitu langit dijunjung" sehingga budaya adat istiadat masyarakat Dayak kurang dihormati atau diabaikan. Terjadinya benturan budaya antara warga masyarakat asal etnis Madura yang 
sejak lama menerapkan sikap dan perilaku "kekerasan" dalam berbagai bentuk yang berlatar belakang "budaya carok" yang sangat bertentangan dengan budaya dan adat-istiadat/adat kebiasaan dalam kehidupan masyarakat Dayak di Kalimantan Tengah yang memegang budaya falsafah hidup Huma betang. (LSM PBBKT, 2003: 4)

Sejalan dengan kesimpulan di atas, konflik sosial dan budaya menurut budayawan Anshory Djausal (dalam http://antaranews.com: 2012) dapat diatasi dengan solusi budaya, karena tetap ada nilai-nilai budaya universal yang dapat mempertemukan dua masyarakat yang berbeda." Lebih lanjut Mar'at dan Kartono (2006: 82) menjelaskan bahwa "budaya juga dapat dilihat sebagai jalan keluar atau solusi bagi masalah secara pribadi maupun kelompok, karena apa yang dipikirkan, diinginkan, dirasakan, dan dikerjakan banyak ditentukan oleh budaya setempat." Munawar (dalam Abubakar, 2010: 5) mengemukakan bahwa "konflik atas nama kelompok tidak akan pernah terjadi di Kalimantan Tengah, jika falsafah budaya huma betang dengan seperangkat nilai yang terkandung di dalamnya telah mengikat hubungan emosional dan kekerabatan di antara mereka". Dalam hal ini peneliti berpendapat bahwa nilai-nilai hidup budaya huma betang tepat untuk mempertemukan keberagaman etnis, agama, kelompok dan lain-lain di Kalimantan Tengah.

Berdasarkan keterangan di atas, nilai-nilai dalam budaya lokal dapat menjadi kekuatan untuk lebih mengokohkan layanan bimbingan kelompok di sekolah terutama yang berkaitan dengan bidang bimbingan sosial sehingga mendorong peneliti untuk melakukan penelitian dengan mengangkat judul "Pengembangan Model Bimbingan Kelompok Berbasis Nilai-Nilai Budaya Huma Betang Untuk Mengurangi Prasangka Sosial Siswa SMA Negeri di Palangka Raya".

\subsection{Rumusan Masalah}

1. Bagaimana kondisi faktual pelaksanaan bimbingan kelompok di SMA Negeri Palangka Raya? 
2. Bagaimana model bimbingan kelompok berbasis nilai-nilai budaya huma betang untuk mengurangi prasangka sosial siswa SMA Negeri di Palangka Raya?

3. Bagaimana tingkat keefektifan model bimbingan kelompok berbasis nilainilai budaya huma betang untuk mengurangi prasangka sosial siswa SMA Negeri di Palangka Raya?

\subsection{Tujuan Penelitian}

1. Mengetahui dan mendeskripsikan kondisi faktual pelaksanaan bimbingan kelompok di SMA Negeri Palangka Raya.

2. Menghasilkan model bimbingan kelompok berbasis nilai-nilai budaya huma betang untuk mengurangi prasangka sosial siswa SMA Negeri di Palangka Raya.

3. Mengetahui tingkat keefektifan model bimbingan kelompok berbasis nilainilai budaya huma betang untuk mengurangi prasangka sosial siswa SMA Negeri di Palangka Raya.

\section{Metode Penelitian}

\subsection{Metode Pengembangan}

Penelitian ini menggunakan metode penelitian dan pengembangan (research and development). Metode penelitian dan pengembangan merupakan metode yang digunakan untuk menghasilkan produk tertentu, dan menguji keefektifan produk tersebut (Sugiyono, 2009: 407). Dasar pertimbangan penggunaan pendekatan ini adalah pendapat Borg dan Gall bahwa strategi penelitian dan pengembangan efektif untuk mengembangkan dan memvalidasikan produk pendidikan.

\subsection{Prosedur Pengembangan Model}

Penelitian ini merupakan penelitian yang menggunakan metode Research and Development (R\& D) dengan langkah-langkah penelitian sebagai berikut: (1) Tahap studi pendahuluan; (2) Merancang Model Hipotetik; (3) Uji Kelayakan model hipotetik; (4) Penyusunan Model Awal; (5) Uji Efektivitas Model Awal; (6) Hasil Akhir Produk (Model Akhir).

\subsection{Subjek Penelitian}




\subsubsection{Subjek Uji Ahli}

Dalam uji coba ahli, bimbingan kelompok berbasis nilai-nilai budaya huma betang di validasi oleh empat orang ahli/ pakar bimbingan kelompok. Data hasil validasi ahli, berupa pendapat, kritik dan saran yang akan dianalisa secara deskripsi dan dijadikan acuan dalam membuat revisi model hipotetik.

\subsubsection{Subjek Uji Praktisi}

Dalam uji coba ahli, bimbingan kelompok berbasis nilai-nilai budaya huma betang di validasi oleh delapan praktisi pelaksana layanan bimbingan kelompok. Data hasil validasi praktisi ini, berupa pendapat, kritik dan saran yang akan dianalisis secara deskripsi dan dijadikan acuan dalam membuat revisi model hipotetik.

\subsubsection{Subjek Uji Efektifitas}

Penelitian ini dilaksanakan di SMA 2 Negeri Palangka Raya yang menjadi lokasi penelitian. Pada tahap studi pendahuluan, subjek yang dipilih adalah siswa kelas X dari semua jurusan.

\subsection{Teknik Pengumpulan Data}

Instrumen penelitian adalah alat yang digunakan oleh peneliti dalam mengumpulkan data agar mempermudah pekerjaannya dan memperoleh hasil yang lebih baik, lebih cermat, lengkap, serta sistematis. Instrumen dalam penelitian ini digunakan untuk mengungkap data kualitatif dan data kuantitatif.

\subsection{Teknik Analisis Data}

Penelitian ini menggunakan 2 metode penelitian yaitu kualitatif dan kuantitatif secara terpadu, maka teknik analisa data pun dilakukan secara terpadu. Analisis data dalam penelitian ini diarahkan dalam 3 tahap, yakni:

\subsubsection{Tahap Pertama}

Analisis data penelitian pada tahap pertama dilakukan secara kuantitatif dan kualitatif. Prosedur kuantitatif dilakukan dengan menghitung prosentase tingkat prasangka sosial siswa. Prosedur kualitatif dilakukan untuk memaknai deskripsi kondisi objektif pelaksanaan layanan bimbingan kelompok di sekolah. Hasil analisis ini dijadikan dasar untuk menyusun model hipotetik awal. Analisis 
data yang digunakan dalam penelitian ini adalah analisis data deskriptif prosentase.

\subsubsection{Tahap Kedua}

Analisis data pada tahap ke-2 menggunakan prosedur kualitatif. Bentuk analisisnya adalah uji kelayakan model dengan mempertimbangkan masukan dari validator ahli dan praktisi. Hasil dari analisis ini digunakan untuk melakukan perbaikan dari model hipotetik awal (model teruji 1).

\subsubsection{Tahap Ketiga}

Bentuk analisis kualitatif yang dilakukan adalah menelaah proses implementasi model yang akan digunakan sebagai dasar untuk menyusun model akhir bimbingan kelompok berbasis nilai-nilai budaya huma betang untuk mengurangi prasangka sosial siswa. Sedangkan untuk menganalisis keefektifan dari model bimbingan kelompok berbasis nilai-nilai budaya huma betang untuk mengurangi prasangka sosial siswa sebelum dan sesudah mengikuti bimbingan kelompok menggunakan desain pre eksperimental: one group pretest - post test design. Untuk pengujian hipotesis digunakan analisis data kuantitatif dengan teknik statistik non-parametris, yaitu menggunakan Tes Ranking Bertanda (Wilcoxon Test).

Hipotesis tindakan pada penelitian ini adalah model bimbingan kelompok berbasis nilai-nilai budaya huma betang untuk mengurangi prasangka sosial pada siswa kelas X SMA Negeri 2 Palangka Raya. Hipotesis tersebut adalah hipotesis asli/alternatif (Ha). Untuk pengujian Ha diubah menjadi hipotesi nol (Ho), model layanan bimbingan kelompok berbasis nilai-nilai budaya huma betang untuk mengurangi prasangka sosial pada siswa kelas X SMA Negeri 2 Palangka Raya. Dalam pembuktian $\mathrm{Ha}$ dan Ho akan diterima atau ditolak maka jumlah rangking/jenjang yang kecil kita bandingkan dengan tabel harga-harga kritis dalam tes Wilcoxon dengan taraf kesalahan 5\%.

\section{Hasil Dan Pembahasan}

Secara kuantitatif menurunnya tingkat prasangka sosial siswa bisa dilihat dari perbandingan nilai evaluasi awal dan evaluasi akhir yang diperoleh masing- 
masing anggota kelompok. Berikut rincian perolehan skor evaluasi awal dan evaluasi akhir anggota kelompok pada semua indikator:

Tabel 1. Perolehan Skor Total Evaluasi Awal dan Evaluasi Akhir Tingkat Prasangka Sosial Siswa

\begin{tabular}{|c|c|c|c|c|c|c|c|}
\hline No. & $\begin{array}{l}\text { Anggota } \\
\text { Kelompok }\end{array}$ & $\begin{array}{c}\text { Frekuensi } \\
\%\end{array}$ & Eval. Awal & Kategori & $\begin{array}{l}\text { Eval } \\
\text { Akhir }\end{array}$ & Kategori & Pengurangan \\
\hline \multirow[t]{2}{*}{1} & A28 & $\mathrm{F}$ & 169 & $\mathrm{~T}$ & 76 & SR & -93 \\
\hline & & $\%$ & 70,42 & & 31,66 & & 38,76 \\
\hline \multirow[t]{2}{*}{2} & B5 & $\mathrm{F}$ & 197 & $\mathrm{~T}$ & 86 & SR & -111 \\
\hline & & $\%$ & 82,08 & & 35,83 & & 46,25 \\
\hline \multirow[t]{2}{*}{3} & B9 & $\mathrm{F}$ & 99 & $\mathrm{R}$ & 71 & SR & -28 \\
\hline & & $\%$ & 41,25 & & 29,58 & & 11,67 \\
\hline \multirow[t]{2}{*}{4} & A6 & $\mathrm{F}$ & 225 & ST & 122 & $\mathrm{R}$ & -103 \\
\hline & & $\%$ & 93,75 & & 50,83 & & 42,92 \\
\hline \multirow[t]{2}{*}{5} & $\mathrm{C} 1$ & $\mathrm{~F}$ & 97 & $\mathrm{R}$ & 68 & SR & -29 \\
\hline & & $\%$ & 40,42 & & 28,33 & & 12,09 \\
\hline \multirow[t]{2}{*}{6} & D3 & $\mathrm{F}$ & 191 & $\mathrm{~T}$ & 91 & $\mathrm{R}$ & -100 \\
\hline & & $\%$ & 79,58 & & 37,91 & & 41,67 \\
\hline \multirow[t]{2}{*}{7} & E7 & $\mathrm{F}$ & 104 & $\mathrm{R}$ & 94 & $\mathrm{R}$ & -10 \\
\hline & & $\%$ & 43,33 & & 39,16 & & 4,17 \\
\hline \multirow[t]{2}{*}{8} & E22 & $\mathrm{F}$ & 236 & ST & 130 & S & -106 \\
\hline & & $\%$ & 98,33 & & 54,16 & & 44,17 \\
\hline \multirow{2}{*}{\multicolumn{2}{|c|}{ Rata-rata }} & & 164,74 & $\mathrm{~S}$ & 92,25 & $\mathrm{R}$ & $-72,49$ \\
\hline & & & 68,65 & $\mathrm{~S}$ & 38,53 & & 30,12 \\
\hline
\end{tabular}

Berdasarkan tabel 1 terlihat bahwasanya prasangka sosial pada semua siswa yang menjadi anggota kelompok mengalami penurunan (nilai evaluasi awal lebih tinggi dari nilai evaluasi akhir).

Tabel 2 Skor Evaluasi Awal dan Evaluasi Akhir Indikator Menunjukkan adanya corak hubungan yang hanya dengan golongan sendiri/in-group dan out-group

\begin{tabular}{cccccccc}
\hline No. & $\begin{array}{c}\text { Anggota } \\
\text { Kelompok }\end{array}$ & $\begin{array}{c}\text { Frekuensi } \\
\text { \% }\end{array}$ & $\begin{array}{c}\text { Eval. } \\
\text { Awal }\end{array}$ & Kategori & $\begin{array}{c}\text { Eval. } \\
\text { Akhir }\end{array}$ & Kategori & Pengurangan \\
\hline $\mathbf{1}$ & A6 & $\mathrm{F}$ & 54 & $\mathrm{ST}$ & 18 & $\mathrm{SR}$ & -36 \\
& & $\%$ & 98,18 & & 32,73 & & 65,45 \\
$\mathbf{2}$ & $\mathrm{A} 28$ & $\mathrm{~F}$ & 39 & $\mathrm{~T}$ & 22 & $\mathrm{R}$ & -17 \\
& & $\%$ & 70,91 & & 40 & & 30,91 \\
$\mathbf{3}$ & $\mathrm{B} 5$ & $\mathrm{~F}$ & 42 & $\mathrm{~T}$ & 19 & $\mathrm{SR}$ & -23 \\
& & $\%$ & 76,36 & & 34,55 & & 41,81 \\
$\mathbf{4}$ & $\mathrm{B} 9$ & $\mathrm{~F}$ & 27 & $\mathrm{R}$ & 15 & $\mathrm{SR}$ & -12 \\
& & $\%$ & 49,09 & & 27,27 & & 21,82 \\
$\mathbf{5}$ & $\mathrm{C} 1$ & $\mathrm{~F}$ & 27 & $\mathrm{R}$ & 20 & $\mathrm{R}$ & -7 \\
& & $\%$ & 49,09 & & 36,36 & & 12,73 \\
$\mathbf{6}$ & $\mathrm{D} 3$ & $\mathrm{~F}$ & 45 & $\mathrm{~T}$ & 23 & $\mathrm{R}$ & -22 \\
& & $\%$ & 81,82 & & 41,82 & & 40 \\
$\mathbf{7}$ & $\mathrm{E} 7$ & $\mathrm{~F}$ & 27 & $\mathrm{R}$ & 22 & $\mathrm{R}$ & -5 \\
& & $\%$ & 49,09 & & 40 & & 9,09 \\
$\mathbf{8}$ & $\mathrm{E} 22$ & $\mathrm{~F}$ & 55 & $\mathrm{ST}$ & 33 & $\mathrm{~S}$ & -22 \\
& & $\%$ & 100 & & 60 & & 40 \\
\hline
\end{tabular}

Jurnal Insight Fakultas Psikologi Universitas Muhammadiyah Jember | 244 


\begin{tabular}{cccccc}
\hline Rata-rata & 39,5 & \multirow{2}{*}{$\mathrm{T}$} & 21,5 & $\mathrm{R}$ & -18 \\
& 71,82 & & 39,09 & & 32,73 \\
\hline
\end{tabular}

Berdasarkan tabel 2, menunjukkan bahwa penurunan rata-rata indikator Menunjukkan adanya corak hubungan yang hanya dengan golongan sendiri/ingroup dan out-group mencapai angka -18 (32,73\%).

Tabel 3 Skor Evaluasi Awal dan Evaluasi Akhir Indikator Selalu menonjolkan kelompok sendiri

\begin{tabular}{cccccccc}
\hline No. & $\begin{array}{c}\text { Anggota } \\
\text { Kelompok }\end{array}$ & $\begin{array}{c}\text { Frekuensi } \\
\text { \% }\end{array}$ & $\begin{array}{c}\text { Eval. } \\
\text { Awal }\end{array}$ & Kategori & $\begin{array}{c}\text { Eval } \\
\text { Akhir }\end{array}$ & Kategori & Pengurangan \\
\hline $\mathbf{1}$ & $\mathrm{A} 28$ & $\mathrm{~F}$ & 38 & $\mathrm{~T}$ & 18 & $\mathrm{SR}$ & -20 \\
& & $\%$ & 69,09 & & 32,73 & & 36,36 \\
$\mathbf{2}$ & $\mathrm{B} 5$ & $\mathrm{~F}$ & 40 & $\mathrm{~T}$ & 27 & $\mathrm{R}$ & -13 \\
& & $\%$ & 72,73 & & 49,09 & & 23,64 \\
$\mathbf{3}$ & $\mathrm{B} 9$ & $\mathrm{~F}$ & 20 & $\mathrm{SR}$ & 18 & $\mathrm{SR}$ & -2 \\
& & $\%$ & 36,36 & & 32,73 & & 3,63 \\
$\mathbf{4}$ & $\mathrm{A} 6$ & $\mathrm{~F}$ & 48 & $\mathrm{ST}$ & 27 & $\mathrm{R}$ & -21 \\
& & $\%$ & 87,27 & & 49,09 & & 38,18 \\
$\mathbf{5}$ & $\mathrm{C} 1$ & $\mathrm{~F}$ & 20 & $\mathrm{SR}$ & 14 & $\mathrm{SR}$ & -6 \\
& & $\%$ & 36,36 & & 25.45 & & 10,91 \\
$\mathbf{6}$ & $\mathrm{D} 3$ & $\mathrm{~F}$ & 42 & $\mathrm{~T}$ & 20 & $\mathrm{SR}$ & -22 \\
& & $\%$ & 76,36 & & 36,36 & & 40 \\
$\mathbf{7}$ & $\mathrm{F} 7$ & $\mathrm{~F}$ & 20 & $\mathrm{SR}$ & 20 & $\mathrm{SR}$ & - \\
& & $\%$ & 36,36 & & 36,36 & & - \\
$\mathbf{8}$ & E22 & $\mathrm{F}$ & 55 & $\mathrm{ST}$ & 28 & $\mathrm{R}$ & -27 \\
& & $\%$ & 100 & & 50,91 & & -14 \\
& \multirow{2}{*}{ Rata-rata } & & 35 & $\mathrm{~S}$ & 21 & $\mathrm{R}$ & 25,23 \\
\hline
\end{tabular}

Berdasarkan tabel 3 menunjukkan bahwa penurunan rata-rata indikator menunjukkan Selalu menonjolkan kelompok sendiri sehingga pada kelompok sendiri bercorak positif sedangkan kelompok lain bercorak negatif mencapai angka yaitu $-14(25,23 \%)$.

Tabel 4 Skor Evaluasi Awal dan Evaluasi Akhir Indikator Kecenderungan berpikir secara stereotif

\begin{tabular}{cccccccc}
\hline No. & $\begin{array}{c}\text { Anggota } \\
\text { Kelompok }\end{array}$ & $\begin{array}{c}\text { Frekuensi } \\
\text { \% }\end{array}$ & $\begin{array}{c}\text { Eval. } \\
\text { Awal }\end{array}$ & Kategori & $\begin{array}{c}\text { Eval } \\
\text { Akhir }\end{array}$ & Kategori & Pengurangan \\
\hline $\mathbf{1}$ & A28 & F & 24 & S & 12 & SR & -12 \\
& & $\%$ & 60 & & 30 & & 30 \\
$\mathbf{2}$ & B5 & F & 36 & ST & 12 & SR & -24 \\
& & $\%$ & 90 & & 30 & & 60 \\
$\mathbf{3}$ & B9 & F & 17 & R & 11 & SR & -6 \\
& & $\%$ & 42,5 & & 27,50 & & 15 \\
$\mathbf{4}$ & A6 & F & 37 & ST & 18 & R & -19 \\
& & $\%$ & 92,5 & & 45 & & 47,5 \\
$\mathbf{5}$ & C1 & F & 17 & R & 12 & SR & -5 \\
& & $\%$ & 42,5 & & 30 & & 12,5 \\
$\mathbf{6}$ & D3 & F & 31 & T & 17 & R & -14 \\
\hline
\end{tabular}




\begin{tabular}{llcccccc}
\hline & & $\%$ & 77,5 & & 42,50 & & 35 \\
7 & E7 & $\mathrm{F}$ & 17 & $\mathrm{R}$ & 18 & $\mathrm{R}$ & 1 \\
& & $\%$ & 42,5 & & 45 & & 2,5 \\
& $\mathrm{E} 22$ & $\mathrm{~F}$ & 40 & $\mathrm{ST}$ & 28 & $\mathrm{~T}$ & -12 \\
& & $\%$ & 100 & & 70 & & 30 \\
& \multirow{2}{*}{ Rata-rata } & & 27 & $\mathrm{~S}$ & 16 & $\mathrm{R}$ & -11 \\
& & & 68,44 & & 40 & & 28,44 \\
\hline
\end{tabular}

Berdasarkan tabel 4 menunjukkan bahwa penurunan rata-rata indikator Kecenderungan berpikir secara stereotif mencapai angka -11 atau 28,44\%.

Tabel 5 Skor Evaluasi Awal dan Evaluasi Akhir Indikator Kecenderungan selalu memuja kekuasaan yang dimiliki oleh kelompok sendiri

\begin{tabular}{|c|c|c|c|c|c|c|c|}
\hline No. & $\begin{array}{l}\text { Anggota } \\
\text { Kelompok }\end{array}$ & $\begin{array}{c}\text { Frekuensi } \\
\%\end{array}$ & $\begin{array}{l}\text { Eval. } \\
\text { Awal }\end{array}$ & Kategori & $\begin{array}{l}\text { Eval } \\
\text { Akhir }\end{array}$ & Kategori & Pengurangan \\
\hline \multirow[t]{2}{*}{1} & A28 & $\mathrm{F}$ & 33 & $\mathrm{~T}$ & 12 & SR & -21 \\
\hline & & $\%$ & 82,5 & & 30 & & 52,5 \\
\hline \multirow[t]{2}{*}{2} & B5 & F & 35 & ST & 10 & SR & -25 \\
\hline & & $\%$ & 87,5 & & 25 & & 62,5 \\
\hline \multirow[t]{2}{*}{3} & B9 & $\mathrm{F}$ & 16 & $\mathrm{R}$ & 13 & SR & -3 \\
\hline & & $\%$ & 40 & & 32,50 & & 7,5 \\
\hline 4 & A6 & $\begin{array}{l}\mathrm{F} \\
\%\end{array}$ & $\begin{array}{l}36 \\
90\end{array}$ & ST & $\begin{array}{l}20 \\
50\end{array}$ & $\mathrm{R}$ & $\begin{array}{c}-16 \\
40\end{array}$ \\
\hline \multirow[t]{2}{*}{5} & $\mathrm{C} 1$ & $\mathrm{~F}$ & 17 & $\mathrm{R}$ & 9 & SR & -8 \\
\hline & & $\%$ & 42,5 & & 22,50 & & 20 \\
\hline \multirow[t]{2}{*}{6} & D3 & $\mathrm{F}$ & 33 & $\mathrm{~T}$ & 13 & SR & -20 \\
\hline & & $\%$ & 82,5 & & 32,50 & & 50 \\
\hline \multirow[t]{2}{*}{7} & E7 & F & 21 & $\mathrm{~S}$ & 12 & SR & -9 \\
\hline & & $\%$ & 52,5 & & 30 & & 22,5 \\
\hline \multirow[t]{4}{*}{8} & E22 & F & 36 & ST & 12 & SR & -24 \\
\hline & & $\%$ & 90 & & 30 & & 60 \\
\hline & \multirow{2}{*}{\multicolumn{2}{|c|}{ Rata-rata }} & 28 & $\mathrm{~T}$ & 13 & SR & -16 \\
\hline & & & 70,9 & 1 & 31,56 & & 39,37 \\
\hline
\end{tabular}

Berdasarkan tabel 5 menunjukkan bahwa penurunan rata-rata indikator Kecenderungan selalu memuja kekuasaan yang dimiliki oleh kelompok sendiri mencapai angka $-16(39,37 \%)$.

Tabel 6 Skor Evaluasi Awal dan Evaluasi Akhir Indikator Adanya sikap bermusuhan terhadap kelompok lain

\begin{tabular}{cccccccc}
\hline No. & $\begin{array}{c}\text { Anggota } \\
\text { Kelompok }\end{array}$ & $\begin{array}{c}\text { Frekuensi } \\
\text { \% }\end{array}$ & $\begin{array}{c}\text { Eval. } \\
\text { Awal }\end{array}$ & Kategori & $\begin{array}{c}\text { Eval } \\
\text { Akhir }\end{array}$ & Kategori & Pengurangan \\
\hline $\mathbf{1}$ & A28 & F & 35 & T & 12 & SR & -21 \\
& & $\%$ & 70 & & 24 & & 52,5 \\
2 & B5 & F & 44 & ST & 18 & SR & -25 \\
& & $\%$ & 88 & & 36 & & 62,5 \\
3 & B9 & F & 19 & R & 14 & SR & -3 \\
& & \% & 38 & & 28 & & 7,5 \\
$\mathbf{4}$ & A6 & F & 50 & ST & 39 & T & -16 \\
\hline
\end{tabular}

Jurnal Insight Fakultas Psikologi Universitas Muhammadiyah Jember | 246 


\begin{tabular}{cccccccc}
\hline \multirow{5}{5}{} & $\mathrm{C} 1$ & $\%$ & 100 & & 78 & & 40 \\
& & $\mathrm{~F}$ & 16 & $\mathrm{SR}$ & 13 & $\mathrm{SR}$ & -8 \\
$\mathbf{6}$ & $\mathrm{D} 3$ & $\mathrm{~F}$ & 32 & & 26 & & 20 \\
& & $\%$ & 40 & $\mathrm{~T}$ & 18 & $\mathrm{SR}$ & -20 \\
$\mathbf{7}$ & $\mathrm{E} 7$ & $\mathrm{~F}$ & 19 & $\mathrm{R}$ & 22 & $\mathrm{~S}$ & 50 \\
& & $\%$ & 38 & & 44 & & -9 \\
$\mathbf{8}$ & $\mathrm{E} 22$ & $\mathrm{~F}$ & 50 & $\mathrm{ST}$ & 29 & $\mathrm{~S}$ & -24 \\
& & $\%$ & 100 & & 58 & & 60 \\
& & 34 & $\mathrm{~S}$ & 21 & $\mathrm{R}$ & -13 \\
& Rata-rata & & 68,25 & & 41,25 & & 27 \\
\hline
\end{tabular}

Berdasarkan tabel 6 menunjukkan penurunan rata-rata indikator adanya sikap bermusuhan terhadap kelompok lain mencapai angka $-13(27 \%)$. Uji keefektifan model layanan bimbingan kelompok berbasis nilai-nilai budaya huma betang untuk mengurangi prasangka sosial siswa SMA dianalisis dengan statistik non-parametrik melalui uji Wilcoxon. Berikut ini adalah hasil uji efektifitas model yang dikembangkan pada perolehan skor total prasangka sosial:

Tabel. 7 Wilcoxon Signed Ranks TestRanks

\begin{tabular}{|c|c|c|c|c|}
\hline \multicolumn{5}{|l|}{ Ranks } \\
\hline & & $\mathrm{N}$ & Mean Rank & Sum of Ranks \\
\hline \multirow{4}{*}{$\begin{array}{l}\text { Pretest } \\
\text { - } \\
\text { Postest }\end{array}$} & Negative Ranks & $8^{\mathrm{a}}$ & 4,50 & 36,00 \\
\hline & Positive Ranks & $0^{\mathrm{b}}$ &, 00 &, 00 \\
\hline & Ties & $0^{c}$ & & \\
\hline & Total & 8 & & \\
\hline
\end{tabular}

Berdasarkan tabel 7 diperoleh kesimpulan bahwa 8 orang anggota kelompok yang telah mengikuti kegiatan bimbingan kelompok berbasis nilai-nilai budaya huma betang mengalami penurunan tingkat prasangka sosial.

Tabel. 8 Hasil Uji Wilcoxon

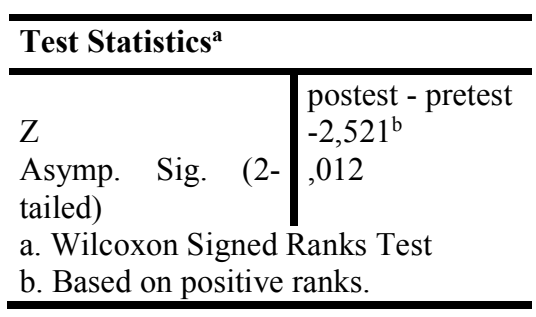

Berdasarkan hasil dari perhitungan di Tabel 8 bahwa nilai $\mathrm{Z}$ yang didapat sebesar -2,521 dengan $p$ value (Asymp. Sig 2 tailed) sebesar 0,012 di mana 
kurang dari batas kritis penelitian 0,05 maka Ho (Hipotesis Nol) di tolak dan Ha (Hipotesis Alternatif) di terima sehingga dapat disimpulkan bahwa model bimbingan kelompok berbasis nilai-nilai budaya huma betang terbukti efektif untuk mengurangi prasangka sosial siswa SMA negeri 2 di Palangka Raya.

\section{Kesimpulan dan Saran}

\section{Kesimpulan}

Dari hasil penelitian yang dilaksanakan, maka dapat diambil kesimpulan sebagai berikut:

1. Bimbingan kelompok sudah dilaksanakan di SMA Negeri Palangka Raya dengan melewati 4 tahapan, yakni tahap pembentukan, tahap peralihan, tahap kegiatan, dan tahap pengakhiran. Namun, karena kurangnya ketersediaan waktu, bimbingan kelompok dilaksanakan hanya pada saat jam pelajaran kosong dan jumlah anggota kelompok terlalu banyak yaitu 1 (satu) kelas atau lebih dari 12 orang identik dengan bimbingan klasikal. Layanan diberikan secara insidental, artinya guru BK hanya melaksanakan bimbingan kelompok ketika masalah itu sudah muncul pada siswa. Materi bimbingan kelompok di SMA Negeri di Palangka Raya yang diberikan hanya mengulang dari tahun-tahun sebelumnya yaitu materi tentang motivasi belajar dan materi belajar secara efektif sehingga cenderung monoton dan kurang variatif. Pembahasan materi bimbingan kelompok yang berkenaan dengan prasangka sosial tidak pernah diberikan dan nilainilai budaya lokal belum di berdayakan dalam pelaksanaan bimbingan kelompok di SMA Negeri Palangka Raya.

2. Rumusan model bimbingan kelompok berbasis nilai-nilai budaya huma betang terdiri dari 6 komponen, yakni (1) Rasional; (2) Visi dan Misi;(3) Tujuan; (4) Isi Bimbingan Kelompok; (5) Pendukung Sistem; (6) Bimbingan Kelompok Berbasis Budaya Huma Betang. Kelayakan model tersebut sudah divalidasi oleh 3 pakar bimbingan dan konseling serta 1 pakar budaya, serta 7 Praktisi yaitu guru bimbingan dan konseling. Hasil 
uji kelayakaan menunjukkan bahwa model yang dirancang layak untuk di implementasikan di lapangan.

3. Model bimbingan kelompok berbasis nilai-nilai budaya huma betang secara efektif dapat mengurangi prasangka sosial. Simpulan ini di dasarkan pada hasil skala prasangka sosial, diperoleh hasil adanya penurunan tingkat skala prasangka sosial dari sebelum dan sesudah mengikuti kegiatan bimbingan kelompok berbasis nilai-nilai budaya huma betang.

\section{Saran}

\section{a. Bagi Guru bimbingan dan Konseling}

1. Guru BK hendaknya meningkatkan kompetensinya dalam melaksanakan bimbingan kelompok sehingga layanan yang diberikan dapat optimal dalam mengatasi masalah yang terjadi. Jika masalah tersebut berkaitan dengan kehidupan sosial dan budaya seperti prasangka sosial maka guru BK dapat menyisipkan nilai-nilai kearifan lokal yang kental dengan nilainilai sosial-budaya ke dalam bimbingan kelompok. Oleh karena itu perlu melakukan need assesment terlebih dahulu sebelum memberikan layanan.

2. Model bimbingan kelompok berbasis nilai-nilai budaya huma betang dapat dijadikan sebagai salah satu pilihan oleh guru BK sebagai upaya untuk memberi bantuan bagi siswa khususnya yang berkaitan dengan prasangka sosial.

\section{b. Bagi sekolah}

Sekolah diharapkan dapat memberikan kesempatan, dukungan dan fasilitas kepada guru bimbingan dan konseling untuk melaksanakan bimbingan kelompok berbasis nilai-nilai budaya huma betang.

\section{c. Bagi Peneliti Selanjutnya}

1. Peneliti (lanjutan) diharapkan lebih memperhatikan proses terbentuknya dinamika kelompok terutama keaktifan anggota kelompok mengambil manfaat dari pembahasan permasalahan anggota kelompok yang lain.

2. Penelitian ini hanya menjadikan seluruh siswa kelas $X$ sebagai subjek penelitian, sehingga peneliti selanjutnya disarankan untuk mengikutsertakan siswa dalam seluruh tingkatan kelas sehingga 
keefektifan hasil pemberian layanan mampu digeneralisir secara lebih luas lagi.

3. Persoalan mengenai tingginya tingkat prasangka sosial siswa tidak hanya terjadi di SMA Negeri di Palangka Raya, tetapi juga di sekolah dan daerah lainnya. Oleh karena itu bagi peneliti selanjutnya di sarankan agar mampu mengembangkan model bimbingan kelompok atau jenis bimbingan lainnya dengan memanfaatkan nilai-nilai budaya lokal yang ada di budaya setempat.

\section{DAFTAR PUSTAKA}

Corey, G. 2012. Theory and Practice of Group Counseling (Eight Edition). Brools/Cole Publishing Company: USA.

Farley, J. 2010. Majority-Minority Relations. USA: Prentice Hall.

Fitri, A. Z. 2012. Pendidikan Karakter Berbasis Nilai dan Etika di Sekolah. Jakarta: AR-Ruzzmedia

Fitria, N. 2013. Model Bimbingan Kelompok Berbasis Falsafah Hidup Masyarakat Lampung Untuk Mengurangi Prasangka Sosial Siswa. Tesis. Semarang: Program Pascasarjana UNNES.

LSM PBBKT. 2003. Adat Istiadat Dayak Ngaju. Palangka Raya: LSM Pusat Budaya Betang Kalimantan Tengah.

Muhammad \& Abubakar. M. 2010. Falsafah Hidup Budaya Huma Betang dalam Membangun Kerukunan Hidup Umat Beragama di Kota Palangka Raya Kalimantan Tengah. Malang: Aditya Media

Rahman, F. 2002. Mengelola prasangka sosial dan stereotif etnik-keagamaan melalui psychological and global education. Artikel Elektronik.

Sugiyono. 2007. Statistika Untuk Penelitian.Bandung: CV. Alfabeta Sultra.

Wibowo, M.E, 2005. Konseling kelompok Perkembangan. Semarang: Unnes Press.

Winkel, WS. 2007. Bimbingan dan Konseling: di institusi Pendidikan. Yogyakarta: Media Alba. 